\title{
Neochamanismo urbano. Engaño, abuso y poder en la comunidad carare
}

\author{
Betty Sánchez Sarmiento \\ Bogotá: Editorial Pontificia Universidad Javeriana \\ 2018. $178 \mathrm{pp}$ \\ SOFÍA LARA-LARGO \\ PhD en antropología y sociología, Universidad de Paris VII Diderot. \\ Profesora de la Universidad Tecnológica de Pereira. \\ $\square$ sofia.lara@utp.edu.co \\ (D) ORCID: 0000-0001-8407-3773 \\ $\leadsto$ Google Scholar
}

Esta autoetnografía aborda el proceso de emergencia, consolidación y legitimación de un liderazgo, denominado por la autora como neochamánico, así como la amplia gama de prácticas de poder que éste instauró, cooptando la fe y la confianza de aquellos que se volvieron sus seguidores y súbditos asiduos. La vivencia, por más de diez años en el seno de una comunidad neochamánica urbana, le permite a la narradora hacer un retrato estremecedor de la experiencia vivida y de la manera en que se estableció un fino andamiaje de la creencia, particularmente reglamentado y cooptado, que desembocaría en el despliegue de un régimen de violencia moral, espiritual, de género y sexual. El liderazgo enceguecedor del neochamán, mediado por plantas asociadas a rituales indígenas diversos, como el yajé, el mambe de coca y el ambil, determinaría años de vivencias hiperritualizadas. Estas experiencias, permeadas por visiones altamente estereotipadas del mundo indígena y por la omnipresencia del liderazgo neochamánico, generaron, en algunos miembros de la denominada Comunidad de Paz Carare de Pensamiento Bonito (CPCPB), consecuencias dolorosas y traumáticas. Los fenómenos descritos, a lo largo de esta narración detallada de lugares, de relaciones entre humanos, de encuentros y desencuentros entre humanos y plantas, de hitos vitales 
coyunturales, llevarán a la autora, en su conclusión, a asociar lo vivido con fenómenos más amplios ya conocidos de deriva sectaria.

El libro cuenta con seis secciones que se acompasan por títulos intermedios. Estos guían al lector en la narración de: la experiencia de la autora dentro de la comunidad neochamánica, del afianzamiento del liderazgo de Édgar Orlando Gaitán Camacho y de los mecanismos de legitimación de su autoridad. Se marca el inicio con un relato sobre la vida y la muerte, sobre los debates internos que llevaron a la autora a encontrarse con el yajé, como planta maestra. Esta sección le deja ver al lector cómo se teje el vínculo planta-humano que será determinante en la iniciación de la autora y en su permanencia en la comunidad. En la segunda sección se perciben dos momentos principales. El primero restituye la consolidación de la identidad étnica del neochamán, sus referentes múltiples, las relaciones establecidas con actores disímiles y el establecimiento de redes que favorecieron el reconocimiento de su autoridad. En un segundo momento se narra en qué medida esta etnicidad construida se hizo eficaz en la comunidad, a través de mecanismos de organización social reglamentados que se objetivaron en roles jerarquizados.

La tercera sección deja a la autora adentrarse en los debates sobre la construcción de un territorio ancestral neochamánico, y en cómo la conexión con este territorio permitió una proliferación de rituales de la vida cotidiana, tanto dentro como fuera de él. En el apartado cuatro, se analizan los rituales que tenían lugar, con el fin de evidenciar las prácticas de violencia y de dominación masculina que allí se daban. Se aborda la construcción del concepto de justicia propia que desencadenó castigos, presión y control sobre los cuerpos y las mentes de los miembros de la CPCPB.

La quinta sección está dedicada a las reflexiones sobre contaminación, contagio y fuerzas espirituales asociadas a la feminidad, dejando ver las ambigüedades estratégicas de la representación de la mujer en un sistema regido por interacciones heterosexistas. El último apartado presenta la manera en que se revelan a la autora los testimonios de las mujeres que afirman haber sido abusadas sexualmente por el neochamán y cómo estos relatos conllevan a un doloroso proceso de desencantamiento y al derrumbe de la creencia en la comunidad y en su líder.

La narrativa etnográfica de esta obra se presenta de manera cronológica y está atravesada por tres registros transversales. Por una parte, la descripción restituye permanentemente la vivencia de la autora y en qué medida los aprendizajes, resultado de su adscripción al grupo 
neochamánico, se iban labrando poco a poco en su cuerpo y en su pensamiento. Allí aparece constantemente la narración experiencial, la evocación de lo percibido y el impacto de las relaciones inmediatas, con otros miembros de la comunidad, en las formas de decidir, pensar, creer y vivir en lo cotidiano. Por otra parte, aparece el relato de la emergencia y sedimentación del liderazgo de Édgar Orlando Gaitán Camacho y en su constitución como figura de poder fundada en diferentes nodos de legitimación. Allí encontramos los relatos fundacionales de la CРCPB como grupo social. Además, se restituyen los discursos que buscaron afianzar su autoridad vía la exaltación de un mundo indígena estereotipado y elitizado y a través de la creación de un cuidadoso entramado de actos performativos: la proliferación de rituales, la producción de un territorio (fundación de la Neomaloca en la finca el Sol Naciente) y la ratificación constante de referentes jerárquicos. El tercer registro se manifiesta sobre todo al final del libro, en el momento en que la autora les entrega la palabra a algunas mujeres, quienes, a través de su testimonio, denuncian los actos de violencia sexual protagonizados por el neochamán en contextos casi siempre de carácter ritual. Allí el lector se enfrenta con las dolorosas narraciones de las mujeres vulneradas, y también con las de algunos que sufrieron amenazas e intimidaciones en el marco de las denuncias públicas por estos actos que son objeto de un proceso penal que seguía en curso en el momento de publicación de la obra. En esta sección los relatos son transcritos por la autora y son presentados de manera secuencial, dando lugar a la sonoridad de otras voces en la autoetnografía.

Considero que un primer aporte fundamental de este texto es la descripción detallada de los elementos constitutivos de una autoridad neochamánica que, en un contexto urbano como el bogotano, revelan los principios de una lógica de poder cuidadosamente elaborada. Édgar Orlando Gaitán Camacho encarnó diferentes roles y entidades a través de las que generó niveles cada vez más amplios de legitimidad y control. La autora muestra cómo este hombre se autodefinió: Premio Nobel Alternativo de Paz, "el último Carare" (identidad étnica reclamada asociada a una comunidad indígena aparentemente "extinta"), médico tradicional indígena, taita, abuelo, héroe, santo, padre, sanador, herbolario, líder social y guía espiritual.

Todos estos estatus, evocados en diferentes momentos de la historia de la $\mathrm{CPCPB}$, y en el marco de los múltiples actos performativos, estarían enfocados a generar conexión con una gran variedad de actores aumentando su legitimidad. La autora afirma que la utilización de estas categorías permitieron la emergencia de una imagen de "héroe idealizado", "gurú autoritario", "líder carismático" y "líder espiritual" (p. 18). 
En esta línea, un argumento particularmente interesante tiene que ver con la reflexión que hace la autora sobre la relación del neochamán con el yajé. Ella muestra cómo aquel reclamó una identidad de "chamán-planta" (pp. 79, 91, 126) en contextos rituales:

A través de este discurso, el neochamán instituía sus palabras con un poder más allá de lo humano, venido de lo vegetal, de una planta; planta que encarnaba el espíritu de la divinidad. Al tener la posición de "chamán-planta", sus palabras instituían la disciplina y las normas a seguir, que debían ser experimentadas en la vida del grupo y replicadas sin debatir. (p. 79)

Esta imbricación entre el personaje neochamánico y la planta le permitía, entre otros, generar una idea de omnisapiencia y omnipresencia en el contexto ritual y también en la vida cotidiana, debido a su hiperritualización. La autora narra cómo ella, así como otros miembros de la comunidad, muchas veces daban por hecho que el chamán conocía sus más profundos secretos, porque habían sido revelados en la toma de yajé. Esta dinámica generó poderosos dispositivos de control y manipulación de la voluntad.

Por su parte, las categorías de Premio Nobel Alternativo de Paz (p. 42), e incluso la de campesino (p. 34), también fueron puestas al servicio de la legitimación del neochamán frente a los miembros de la CPCPB. Originario de Santander, él habría tenido que vivir difíciles situaciones en el marco del conflicto armado interno colombiano y defendía su participación activa en la reconocida experiencia de paz de la Asociación de Trabajadores Campesinos del Carare (ATCC). Si bien el título de Premio Nobel Alternativo fue entregado a esta organización en 1999, y no tenía un carácter individual, Gaitán Camacho lo apropió como parte de su estrategia política, autodenominándose "Premio Nobel". Considero que la reivindicación de estas categorías de identificación posibilitó su definición como un sujeto capaz de trastocar lógicas profundas de poder, en un contexto tan adverso como el del conflicto armado. Capacidad que le permitiría investirse de una autoridad como héroe y pacifista. Dicha investidura haría aún más inverosímiles sus actos de violencia y los encubrirían, hasta el final, a través de una representación colectiva sedimentada de un hombre defensor de la paz.

Un segundo aporte que deseo señalar tiene que ver con las reflexiones relativas a los mecanismos de control territorial y justicia establecidos dentro de la comunidad neochamánica. La autora muestra de qué manera se establecieron normas que reprodujeron la dominación masculina y la 
violencia de género, no solamente sexual, en contextos rituales y en la vida cotidiana. El libro cuenta con varios pasajes que describen los rituales, la distribución de los roles y la división sexual del trabajo en diferentes momentos de la historia de este colectivo. Estos pasajes dejan ver la reglamentación de los espacios, la fuerte jerarquización y los mecanismos de la denominada justicia propia (p. 107) que le permitieron al neochamán tener un control total sobre los cuerpos y las vidas de sus seguidores: "relaciones de poder, de dominación, y sujeción, dentro de una reglamentación heterosexista y discriminatoria de lo femenino" (p. 68). En este escenario la justicia aparece como ética, cosmología y práctica cotidiana fundada en una "ley natural":

En este escenario de "justicia propia", desapareció la libertad individual, ya que le delegábamos al neochamán el poder de hacer justicia, la definición de las infracciones, la jerarquía de su gravedad, las formas de castigo dentro de la $\mathrm{CPCPB}$, lo que estaba o no permitido, así como las formas de juzgar o de exposición de los daños. Lo anterior dentro de una relación de sometimiento en la cual "la obediencia es un control completo de la conducta por parte del maestro, y no un estado final de autonomía". (Foucault, 1990, p. 89. Citado en Sánchez Sarmiento, 2018, p. 110)

Las neomalocas fueron territorios construidos en la artificialidad de referentes étnicos indígenas dentro de la Finca El Sol Naciente que fue comprada con dineros de la fundación creada y liderada por el neochamán. La autora hace evidente el nivel de compromiso que muchos miembros tenían con una causa que aparecía en el imaginario colectivo como una alternativa a los modelos mercantiles de la propiedad y de las relaciones humanas. Al contribuir con la fundación, a través del trabajo o el dinero, de manera sistemática, se apelaba a una idea de comunitarismo primigenio. Luego este territorio se reglamentaría a través de prácticas sincréticas e híbridas de control, castigo y vigilancia:

De esta manera, la finca El Sol Naciente se constituyó en un escenario para exhibir y experimentar, contener, proteger y reproducir una experiencia neochamánica de curación, dentro de unos regímenes semióticos de lo étnico (indígena) y a través de la ingesta de plantas, mezclada con prácticas médicas paralelas (homeopatía, terapia neural, acupuntura, quiropraxia, gemoterapia) y prácticas alopáticas. (p. 67)

Es interesante ver cómo el líder neochamánico apropió, resituó y resignificó conceptos propios de las políticas de reconocimiento de las 
comunidades indígenas en el marco del multiculturalismo, como: autonomía, justicia propia y territorio. Las puso al servicio de su proyecto político, a través del referente constante a su identidad étnica (carare) reclamada y a través de un proyecto de recuperación y reconstrucción identitaria, al que varios profesionales formados, como la autora, contribuyeron en los orígenes de la CPCPB.

Estos conceptos, así como otros que ya he podido mencionar en el presente texto, fueron instrumentalizados de la misma manera que poderosos referentes del universo católico. Considero que la falta de un análisis exhaustivo de la manera en que se apropiaron y se manipularon diferentes dimensiones del mundo ritual y de la creencia católica sería uno de los puntos frágiles de esta obra. Pasajes más o menos dispersos permiten al lector inferir el rol fundamental de dicho universo. En este contexto neochamánico se apropió por ejemplo el calendario eclesiástico de manera estratégica y se afianzaron momentos claves de la experiencia ritual vía la temporalidad del mundo católico (p. 70). Se utilizó la presencia y autoridad del sacerdote en los rituales de la ingesta del yajé (pp. 71, 76). Se manipularon y pusieron al servicio de la fijación de la legitimidad ritual del neochamán diversas prácticas con referentes católicos (p. 72, 73, 75, 123) como: la simbología y las representaciones iconográficas (p. 73, 79-80, 123, 124) y los principios de justicia (p. 111, 117) y moral católica (p. 120):

En los conversatorios con los ayudantes, ya no de forma pública, el neochamán establecía la necesidad de trabajar con los referentes católicos -rituales, imágenes, esculturas, símbolos-, ya que producían efectos miméticos, o de sustitución de referentes rituales de raigambre diversa en todos los participantes. El neochamán explicaba que estos podían superponerse unos a otros; en sus palabras, "algunas personas llegarán y se quedarán por las imágenes cristianas y otras por las del yajé". (p. 76)

Este pasaje es tan solo un ejemplo de los abundantes fragmentos con los que cuenta esta etnografía y que le habrían permitido a la autora seguir la pista de cómo se configura justamente una creencia sincrética con fines altamente políticos, el peso relativo de los referentes étnicos y católicos, la continuidad de dichos referentes en el tiempo y sus parámetros de apropiación. La mayoría de los pasajes permiten inferir cómo todo esto era importante para la consolidación de la autoridad del neochamán pero sabemos poco de cómo eran importantes para el afianzamiento de la confianza y la fe de sus seguidores. 
Concluyo insistiendo que esta autoetnografía contribuye a los estudios sobre prácticas urbanas neochamánicas y violencia, en la medida que elabora un retrato cuidadoso de la conjugación de múltiples elementos políticos, religiosos y étnicos desde una observación cercana e intensa en el largo plazo. Los diez años de vivencia dentro de esta comunidad le permitieron a la autora una gran riqueza en los ejemplos y fuentes etnográficas. Este libro muestra cómo la narradora crea una relación con un conjunto de referentes humanos y vegetales a lo largo de su experiencia vital, hace evidente además cómo emerge la figura del líder y el andamiaje de su autoridad. El amplio detalle de la descripción sobre la forma en que se funda y se cimientan la creencia y la confianza deja al lector curioso sobre la manera en que éstas se desmontaron, así como la filigrana del desencantamiento tras las denuncias de los abusos sexuales. Este proceso se trata con menor detalle y cuidado al final de la obra. Sin embargo, la riqueza descriptiva y la valentía que subyace a este intenso relato autobiográfico le otorgan un carácter remarcable. 